the cost of the exhibitions has varied from less than $£ 50$ to more than $£ 3,000$ (the latter cost being borne by the industry concerned).

In his account of the Hancock Museum, Mr. T. Russell Goddard explained that this institution is financed entirely by the Natural History Society of Northumberland, Durham, and Newcastle-uponTyne. It was characteristic of the scientific life of the past century that so much public service had been performed by voluntary effort; but at the present time the finances of the Society are scarcely adequate to maintain the Museum in an effective manner.

Lastly, a valuable account was given by Dr. Kathleen B. Blackburn (Armstrong College) on modern methods of pollen analysis in relation to archæological finds from peat. Mr. H. A. Hyde (National Museum of Wales, Cardiff) also dealt with this subject, and stressed its importance to the museum curator.

On the art side, Dr. John Rothenstein, director of the City Art Galleries, Sheffield, described the work which is being done in his Galleries to give schoolchildren a greater perception and understanding of contemporary art (especially in the form of household objects), while Mr. Richard Bach, of the Metro- politan Museum of Art, discussed the vigorous way in which art collections are brought to the people in New York by the Museum's "Neighbourhood Circulating Exhibitions".

In general discussions the problem of bad museums was considered more than once, and Mr. S. F. Markham (Hon. Empire Secretary, The Museums Association), after carefully defining such museums, advocated that steps should be taken to close them. Dr. C. Hay Murray, in a paper on "Museums as Department Stores", suggested that the curator should regard himself as a salesman, and study the methods of the shopkeeper. No less important, but of a more domestic nature, were papers by $\mathrm{Mr}$. Laurence Vail Coleman, director of the American Association of Museums, on "The Philosophy of a Museums Association", and by Mr. S. D. Cleveland (Manchester) on "The Future of the Museums Association". Judging from the keen interest which the Conference aroused, that future will be an active and successful one.

The next Conference of the Association (of which the headquarters are at Chaucer House, London, W.C.I) will be held at Belfast in the first week of July 1938.

\title{
Flight in the Stratosphere
}

A LL countries which are interested in aviation $A$ have been considering the possibility of extend. ing their activities to aircraft in the stratosphere. The greatest advantage in flying very high is that much higher speeds can be obtained for the same expenditure of power as the density of air is so much lower in the stratosphere than at ground-level. The Schneider trophy was won, for example, at a speed of 430 m.p.h. with an engine which gave 2,200 h.p. In the stratosphere, a speed of about 800 m.p.h. could be obtained for the same power. To drive the Schneider trophy winner at the latter speed near the ground would require an engine of $30,000 \mathrm{~h} . \mathrm{p}$. If stratosphere flight were possible at 600 m.p.h., then New York would be only five hours from London; so that by local time a passenger from London would arrive at New York before he started.

In vol. 7 of the Cambridge University Engineers' Association Year book recently published, Captain J. L. Pritchard points out some of the difficulties involved in flying in the stratosphere, and concludes that these will probably prevent stratosphere flight becoming a regular service, at least in the present generation. In fact, the increasing engine temperatures due to the difficulty of getting greater cooling may make regular flights in the stratosphere impossible until a new source of power is discovered.

The output of the internal combustion engine can only be maintained if the weight of oxygen it takes in per minute is maintained constant. At an altitude of 60,000 feet, the density of air is only about a tenth of what it is at ground-level. To maintain its output the engine would have to run ten times faster than at ground-level or take in ten times the volume of air.
The former alternative is impracticable so the weight of the air would have to be kept constant by supercharging. During this process, the pressure of the air is raised to about that at ground-level and the temperature by about $300^{\circ} \mathrm{F}$. As most of the heat given in the air supplied has to be dissipated, extra cooling is necessary. Despite its low temperature, the low pressure of the atmosphere at this height is a disadvantage. Supercharging requires greater weight of equipment; in fact, the higher the aeroplane the greater its requisite weight.

In 1931, Prof. Picard discovered another fact which increases the difficulties of arranging for cooling. $\mathrm{He}$ found that at a height of ten miles, the temperature outside his gondola was $-67^{\circ} \mathrm{F}$., whilst inside the temperature was $140^{\circ} \mathrm{F}$. This was due to the radiant heat absorbed by the gondola. As a method of getting over these difficulties the rocket principle has been suggested. This doubtless would work better at low temperatures than at the ones at which it has been tried. It has to be remembered also that the velocity of sound in the stratosphere is about 700 m.p.h., a speed which enthusiasts think aircraft might attain. Some engineers think that the aeroplane will have a critical speed at this speed, but it is not known how it would get through this critical speed. For this speed, the aeroplane would probably require small wings and the landing speed might have to be about 130 m.p.h.

As an offset to these disadvantages, there would be a great saving of fuel for the journey and the time would be much shorter. In the event also of an emergency landing, there would be a much greater choice of landing grounds, as it would be possible to travel 140 miles with the engine cut off by gliding from a high altitude. 